\title{
Characterization of a Mixed Methanotrophic Culture Capable of Chloroethylene Degradation
}

\author{
Sydney B. Forrester, ${ }^{1}$ Jong-In Han, ${ }^{1, \dagger}$ Michael J. Dybas, ${ }^{2}$ Jeremy D. Semrau, ${ }^{1}$ \\ and Christian M. Lastoskie, ${ }^{1, *}$ \\ ${ }^{1}$ Department of Civil \& Environmental Engineering \\ University of Michigan \\ Ann Arbor, MI 48109 \\ ${ }^{2}$ Department of Civil \& Environmental Engineering \\ Michigan State University \\ East Lansing, MI 48824
}

\begin{abstract}
A consortium of methanotrophs cultured from the St. Joseph's aquifer in Schoolcraft, MI, was found to exhibit similar methane consumption rates as pure cultures of methanotrophs. The methanotrophic consortium resides within a portion of the aquifer contaminated with a mixed waste plume of perchloroethylene (PCE) and its reductive dechlorination products from natural attenuation, trichloroethylene (TCE), cis-dichloroethylene ( $c$-DCE), and vinyl chloride (VC). Oxidation kinetics for TCE, $c$ DCE, and VC were measured for the mixed methanotroph consortium and compared to reported rate parameters for degradation of these chloroethylene compounds by pure methanotrophic cultures. The results demonstrate that the kinetics of chloroethylene oxidation by the Schoolcraft methanotroph population mimic the degradation rates of pure methanotrophic cultures that primarily express particulate methane monooxygenase (pMMO). Molecular and biochemical analyses confirmed that sMMO was not being expressed by these cells. Rather, using competitive reverse transcriptionpolymerase chain reaction, $p m o A$, a gene encoding one of the polypeptides of the pMMO was found at a level of $(1.57 \pm 0.10) \times 10^{-17} \mathrm{~mol} p m o A \mathrm{mRNA} / \mathrm{g}$ wet soil in soil slurries and $(2.65 \pm 0.43) \times$ $10^{-17} \mathrm{~mol} p m o A \mathrm{mRNA} / \mu \mathrm{l}$ in groundwater. No expression of $m m o X$, a gene encoding one of the polypeptides of the sMMO, was detected.
\end{abstract}

Key words: methanotroph; trichloroethylene; cis-dichloroethylene; vinyl chloride; reverse transcriptionpolymerase chain reaction

\footnotetext{
*Corresponding author: College of Engineering, 1351 Beal Avenue, 181 EWRE Bldg., The University of Michigan, Ann Arbor, MI 48109-2125. Phone: 734-647-7940; Fax: 734-763-2275; E-mail: cmlasto@umich.edu

$\nmid$ Current address: Department of Civil and Environmental Engineering, Rensselaer Polytechnic Institute, Jonsson Engineering Center, Rm. 4049, 110 8th Street, Troy, NY 12180.
} 


\section{INTRODUCTION}

G ROUNDWATER CONTAMINATION by chlorinated solvents is a widespread and persistent problem in the United States. These compounds are used in a multitude of industrial applications, including the production of pharmaceuticals, chemical processing, paint stripping, and dry cleaning (Wiedemeier et al., 1999). Chlorinated solvents such as perchloroethylene (PCE) can be transformed by natural attenuation under anaerobic conditions into other hazardous compounds such as trichloroethylene (TCE), cis-dichloroethylene ( $c$-DCE), and vinyl chloride (VC). The accumulation of $c$-DCE and $\mathrm{VC}$, a known carcinogen, frequently occurs at sites of mixed waste chloroethylene contamination because of the relatively slow biological transformation of these latter substances by reductive dechlorination (Bouwer and McCarty, 1983; Vogel and McCarty, 1985; Distefano et al., 1991).

Because a combination of biotic and abiotic processes are responsible for the natural attenuation that occurs in chloroethylene-contaminated aquifers, large spatial variations are often observed in the concentrations of these compounds within the area of chlorinated solvent intrusion at a polluted site (Wiedemeier et al., 1999). Consequently, multiple treatment strategies have emerged in response to the variety of contaminant profiles encountered in groundwater remediation operations involving destruction of chloroethylenes. These strategies include biostimulation (Middeldorp et al., 1998), bioaugmentation (Steffan et al., 1999), sparging (Heron et al., 2002), emplacement of reactive barriers (Arnold and Roberts, 2000), and redox zone natural attenuation (Morkin et al., 2000).

For the biological treatment approaches, multiple organisms must generally be stimulated or augmented to maximize degradation of the entire set of chlorinated solvents that are present in the aquifer. The removal of TCE, $c$-DCE, and VC under anaerobic conditions has been investigated for methanogens (Bouwer and McCarty, 1983; Vogel and McCarty, 1985; Freedman and Gossett, 1989) and halorespirators (DiStefano et al., 1991; MaymóGatell et al., 1997; Miller et al., 1997; Holliger et al., 1998). Aerobes have also been identified that use $c$-DCE and $\mathrm{VC}$ as sole sources of carbon and energy (Bradley and Chapelle, 2000; Coleman et al., 2002; Verce et al., 2002), or use VC as a primary substrate for the cometabolism of $c$-DCE (Hartmans and de Bont, 1992; Verce et al., 2002). It is presently uncertain what the relative contributions of metabolism and cometabolism are for the in situ biodegradation of these compounds.

As previously noted, slow reductive dechlorination of $\mathrm{VC}$ can lead to the accumulation of this compound under anaerobic conditions. Removal of $c$-DCE and VC under oxic conditions has therefore also been investigated for bacteria that express mono- or dioxygenase enzymes growing on methane, propane, phenol, ammonia, or toluene (Ensley, 1991; Arp, 1995; Wackett, 1995). Methanotrophs, bacteria that express methane monooxygenase (MMO) for the oxidation of methane, express two forms of the enzyme: the cytoplasm-associated or soluble methane monooxygenase (sMMO) and the membrane-bound or particulate methane monooxygenase (pMMO) (Han et al., 1999). Most known methanotrophs express pMMO. The sole known exception, Methylocella palustris, has been isolated from acidic Sphagnum peat bogs. Using standard PCR and DNA:DNA hybridization techniques, M. palustris appears to not have $p m o A$, one of the genes encoding a polypeptide of the pMMO, or at least it has a very divergent sequence such that these experiments could not detect any pmoA-like genes (Dedysh et al., 2000).

Inversely, a small fraction of known methanotrophs can express sMMO (Hanson and Hanson, 1996). The form of MMO being expressed by in situ methanotrophic populations is of great importance for remediation treatment systems, as the oxidation rates of $c$-DCE, TCE, and $\mathrm{VC}$ are orders of magnitude lower than for methanotrophs expressing pMMO than for cells expressing sMMO (Van Hylckama Vlieg et al., 1996; Lontoh and Semrau, 1998; Han et al., 1999).

Biostimulation and bioaugmentation pilot studies are presently being conducted at Schoolcraft Plume G (Fig. 1), a mixed-waste chloroethane/chloroethylene plume near the town of Schoolcraft in southwestern Michigan. A description of this field site is given in the Materials and Methods section. Effective remediation of Plume G requires a multifaceted approach, as no one microbial species is able to degrade all of the compounds present at this site. One strategy presently being evaluated at this site is to stimulate reductive anaerobic dechlorination by halorespiring microbes such as Dehalococcodies. Addition of carbon sources (lactate or palmitic acid) and electron donors to Plume $\mathrm{G}$ sediments has been shown to stimulate degradation of TCE and $c$-DCE under anaerobic conditions (Kim et al., 2001). Bioaugmentation of Plume $\mathrm{G}$ sediments with a halorespiring consortium from the Bachman Road site in Oscoda, MI (He et al., 2002), has also been shown to reduce TCE.

If necessary, a downgradient oxygen delivery zone could be established at the Plume G site in which methanotrophic bacteria are stimulated to degrade any $c$-DCE and $\mathrm{VC}$ that accumulate from reductive dechlorination in the anaerobic biostimulation/bioaugmentation zone. Although no sulfide has been detected in Plume G groundwater downgradient of the anaerobic zone, trace levels of methane have been measured, and formation of $\mathrm{Fe}^{2+}$ was noted in bioaugmentation pilot studies. Moreover, a 


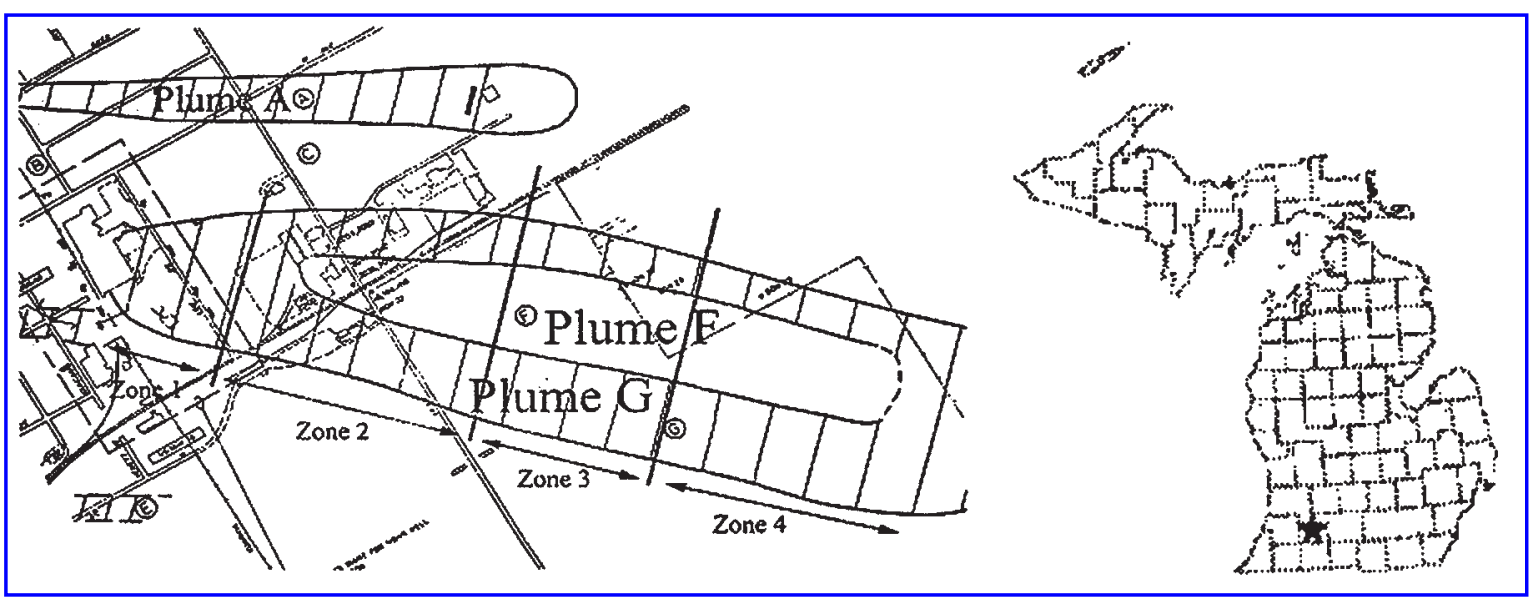

Figure 1. Contaminant plumes at the Schoolcraft, MI, bioremediation site (Heywood, 1993). Plume G is a mixed waste chlorinated solvent plume containing PCE, 1,1,1-TCA and reductive dechlorination products of both compounds from natural attenuation. Also shown are Schoolcraft Plume A, a carbon tetrachloride plume, and Plume F, a chromium/arsenic plume. Both plumes are of separate origin from Plume G.

chemical oxygen demand of up to $500 \mathrm{ppm}$ may be present in the downgradient region from lactate that is supplied to the anaerobic zone. To assess the potential for a sequential treatment process consisting of anaerobic dechlorination followed by an aerobic polishing step, an analysis of the micro-organisms that participate in the oxic zone, and the specific activity expressed by these organisms, was carried out.

We report in this paper measurements of the chloroethylene oxidation kinetics and population analyses of the indigenous methanotroph consortia at the Schoolcraft Plume $\mathrm{G}$ site. Reaction rate studies have been coupled with molecular methods to monitor the specific microbial activity of the Schoolcraft methanotrophs for the degradation of the daughter products of reductive dechlorination of PCE, that is, TCE, $c$-DCE, and VC. Should the accumulation of $c$ DCE or VC from reductive dechlorination warrant a downgradient aerobic biodegradation zone, the activity of the methanotrophs would be stimulated by delivery of oxygen, with methane also supplied to this zone should the generation and migration of methane from the anaerobic zone be insufficient to allow $c$-DCE/VC polishing. We present herein our findings from mixed culture kinetic studies and molecular analyses of the Schoolcraft methanotroph population.

\section{MATERIALS AND METHODS}

\section{Field site}

A section of the St. Joseph aquifer in the village of Schoolcraft, MI, has been contaminated with a mixture of industrial solvents from a plastic and rubber manufacturer.
The aquifer soil is a glacial outwash till of approximately 80 wt.\% sand, and the balance a mixture of clay and silt. The mean diameter of the soil particles is about $200 \mu \mathrm{m}$, and the mass fraction of organic carbon in the soil is low, less than $0.3 \%$. Elevated concentrations of chlorinated solvents have been detected in groundwater samples taken in a region two kilometers long and a half kilometer wide, due southeast from the manufacturing facility in the direction of the natural groundwater gradient. PCE and 1,1,1-trichloroethane (TCA) are the pollutants found in the highest concentration at the contamination source (labeled zone 1 in Fig. 1), with peak concentrations of approximately $200 \mathrm{ppb}$ for both solvents (Heywood, 1993). PCE and TCA daughter products have been formed by intrinsic remediation of the migrating plume; the products of reductive dechlorination by indigenous Schoolcraft microflora include TCE, $c$-DCE, and VC from PCE degradation, and 1,1-dichloroethane from TCA reduction. The concentrations of the daughter products are highest near the center and the advancing front of the plume (zones 2 through 4 in Fig. 1), and approach $1 \mathrm{ppm}$ for TCE and $1.5 \mathrm{ppm}$ for $c$-DCE. No ethene has been detected in the control zones of the aquifer.

\section{Chemicals}

All chemicals used in the preparation of media were of reagent grade or better. Highest purity methane ( $>99.99 \%)$ was obtained from Matheson Co. (Newark, NJ). cisDichloroethylene (97\%) was purchased from Aldrich Chemical Co. (Milwaukee, WI). Vinyl chloride ( $>99.5 \%$ GC grade) and methanol (HPLC, gradient grade) was purchased from Fluka Inc. (Ronkonkoma, NY).

For compounds that are liquid at $25^{\circ} \mathrm{C}$ (TCE and $c$ - 
DCE), stock saturated solutions were prepared by the method of Chang and Alvarez-Cohen (Chang and Alvarez-Cohen, 1996). Stock solutions were added to sample vials using Hamilton 1700 series gas-tight syringes, with care to exclude nonaqueous-phase liquids. For compounds that are gaseous at $25^{\circ} \mathrm{C}$ (VC and methane), samples were added to sample vials using a Dynatech A-2 gas-tight syringes. Methanol was added as a $100 \%$ solution.

Distilled deionized water from a Corning Millipore D2 system was used for all experiments. All glassware was washed with detergent and then acid-washed in $2 \mathrm{M}$ $\mathrm{HNO}_{3}$ overnight to remove trace metals, including copper. The acid was subsequently removed by repeated rinses with distilled deionized water.

\section{Culture conditions}

A Schoolcraft methanotrophic consortium was grown from a soil sample extracted at 65 feet below ground surface from well borings collected during installation of a flux control well at the Plume G site. The consortium was grown from soil immersed in nitrate mineral salt (NMS) medium (Whittenbury et al., 1970) at $30^{\circ} \mathrm{C}$ in batch flasks shaken at $270 \mathrm{rpm}$ in a 1:2 methane-air atmosphere ratio at $1 \mathrm{~atm}$ of pressure. The cultures were grown at $30^{\circ} \mathrm{C}$ to compare the rates of degradation measured here with those collected by others (van Hylckama Vlieg et al., 1996; Han et al., 1999). The culture medium was no more than $15 \%$ of the total flask volume to prevent mass transfer limitation of methane and oxygen from the headspace to liquid medium. For pMMO expression, $2.5 \mu \mathrm{M}$ copper was added aseptically as $\mathrm{Cu}\left(\mathrm{NO}_{3}\right)_{2} \cdot 2.5\left(\mathrm{H}_{2} \mathrm{O}\right)$ after autoclaving and equilibrated for at least 2 days before the media were inoculated (Lontoh and Semrau, 1998). This concentration of copper was added in correspondence to the measured copper concentration of $3.0 \pm 1.5 \mu \mathrm{M}$ in groundwater sampled from various locations in and around Schoolcraft Plume G. Cells were initially grown to the mid- to late-exponential phase $\left(\mathrm{OD}_{600}\right.$ of 0.9$)$, and methane was removed by evacuating the growth flasks five times and allowing air to reequilibrate after each evacuation.

The cells were aseptically diluted threefold into $3 \mathrm{~mL}$ of prewarmed fresh NMS medium with $2.5 \mu \mathrm{M}$ copper and transferred into $20-\mathrm{mL}$ serum vials for an initial $\mathrm{OD}_{600}$ of 0.3 . The vials were capped with Teflon-coated rubber butyl stoppers (Wheaton) and crimp sealed. The appropriate amount of substrate to add was calculated using dimensionless Henry's constants collected from the literature for a pressure of $1 \mathrm{~atm}$ and temperature of $30^{\circ} \mathrm{C}$ : 27.02 for methane (Morel and Hering, 1991); 1.262 for VC (Gosset, 1987); and 0.197 and 0.458 for $c$-DCE and TCE, respectively (Tse et al., 1992).

\section{Kinetic analyses}

To normalize rates of degradation to cell biomass, protein concentrations were measured using the Bio-Rad protein assay kit with bovine serum albumin as a standard. The cells were digested at $90^{\circ} \mathrm{C}$ for $30 \mathrm{~min}$ in $5 \mathrm{~N}$ $\mathrm{NaOH}$. Serial dilutions were prepared to achieve final protein concentrations within the linear range of the assay. The amount of protein was determined by measuring the absorbance at $595 \mathrm{~nm}$ after the Bio-Rad reagent was added. In these experiments, the protein concentration of the cell suspensions varied between 0.09 and 0.1 $\mathrm{mg} / \mathrm{mL}$. For each initial concentration of methane and halogenated hydrocarbons examined in these assays, triplicate samples were created, with duplicate controls made by adding $50 \mu \mathrm{L}$ of $5 \mathrm{M} \mathrm{NaOH}$. Minimal abiotic loss in these killed controls was measured as reported earlier in similar systems (Lontoh and Semrau).

After addition of substrate, the sample vials were shaken at $270 \mathrm{rpm}$ at $30^{\circ} \mathrm{C}$ again to prevent mass transfer from limiting the measured rates of substrate degradation. Exogenous reducing equivalents, formate as sodium formate, were added at a concentration of $20 \mathrm{mM}$. The initial rates of oxidation were determined by measuring the amount of substrate remaining using a HewlettPackard 5890 series II gas chromatograph with an automated headspace sampler, flame ionization detector (FID), and two DB-624 analytical columns (J\&W Scientific Co., Folson, CA). The gas chromatograph was operated with a helium carrier gas flow rate of $5.8 \mathrm{~mL} / \mathrm{min}$, with the injector, oven, and detector temperatures set at 160,80 , and $250^{\circ} \mathrm{C}$, respectively. Initial rates of substrate degradation were determined over time frames dependent on the substrate and the extent of degradation. For methane, a 2-h time frame was used; whereas for VC, $c$ DCE, and TCE, a 5-h time period was selected based upon degradation kinetics previously obtained for $M$. album BG8 (Lontoh and Semrau, 1998). As previously noted, the measured rates of degradation were normalized to the initial protein concentration, and the average initial degradation rate of triplicate samples is reported in this work along with the standard deviation. The kinetic parameters of apparent maximal degradation rate, $V_{\max }\left(\mathrm{nmol} \min ^{-1}\left(\mathrm{mg}\right.\right.$ protein) $\left.{ }^{-1}\right)$ and apparent affinity, $K_{s}(\mu \mathrm{M})$ were determined for methane and for the halogenated hydrocarbons by applying nonlinear regression to the Michaelis-Menten equation using the LevenbergMarquardt algorithm in Polymath 5.0.

\section{Total RNA extraction}

RNA was extracted as described earlier (Han and Semrau, 2004). Briefly, RNase-free disposable plasticware was used, and glassware was oven-baked at $240{ }^{\circ} \mathrm{C}$ for 
4 h. All solutions were made with either RNase-free compounds and diethyl pyrocarbonate (DEPC, Sigma, St. Louis, MO)-treated water, or treated with DEPC.

In the absence of soils, methanotrophic enrichments were performed in Schoolcraft groundwater amended with $0.1 \times$ NMS. The composite groundwater sample was collected from a depth of 60 to 80 feet below ground surface from a flux control well at the Plume $\mathrm{G}$ remediation site. The stimulated methanotrophic cultures were pelleted by centrifugation at $12,000 \mathrm{rpm}$ for $5 \mathrm{~min}$ at $4^{\circ} \mathrm{C}$. The supernatant was removed and the cell pellet was either directly used in the total RNA isolation procedure or frozen and stored at $-80^{\circ} \mathrm{C}$. For lysis, the cells were resuspended in the extraction buffer provided in the Qiagen Total RNeasy kit (Qiagen Inc., Valencia, CA) with $1.6 \mathrm{~g}$ of $0.1 \mathrm{~mm}$ diameter ice-cooled zirconia/silica beads (BioSpec Products, Bartlesville, OK). Cell lysis was performed by bead-beating in a Mini-Bead Beater (BioSpec) six times for $30 \mathrm{~s}$, with $1 \mathrm{~min}$ on-ice between each cycle. After the cells were disrupted, RNA was isolated according to the manufacturer's guidelines.

To monitor gene expression in the presence of soil from the Schoolcraft site, soil slurries were created by mixing $3 \mathrm{~g}$ of soil with $3 \mathrm{~mL}$ of NMS medium in $20 \mathrm{~mL}$ vials. The vials were incubated at $30^{\circ} \mathrm{C}$ and methane consumption monitored periodically using the methodology discussed above. Once noticeable methane consumption was observed $0.5 \mathrm{~g}$ of the soil slurry was transferred into $2 \mathrm{~mL}$ tubes, which were then either directly used in the total RNA isolation procedure or frozen and stored at $-80^{\circ} \mathrm{C}$ for later analysis. After cell lysis as described above, the soil suspension was collected by piercing the bottom of the sample tube with a sterile needle, placing the tube on top of a collection tube in a $15-\mathrm{mL}$ screwcap polypropylene tube, and centrifuging it with the swing bucket centrifuge. One volume of $70 \%$ ethanol was then added to the suspension, and the suspension was passed through a Qiagen column via centrifugation at 4,000 rpm. After removing impurities with Qiagen washing buffers, total RNA was collected with $0.1 \mathrm{~mL}$ of DEPC-treated water at $65^{\circ} \mathrm{C}$. Following treatment with RNase-free DNase I, total RNA was extracted with Qiagen total RNeasy kit.

\section{Competitive RT-PCR assay}

RT-PCR assays were performed with Qiagen OneStep RT-PCR kit (Qiagen Inc.) to monitor and measure the expression of $p m o A$ and $m m o X$, genes encoding polypeptides of the pMMO and sMMO, respectively. The general approach to competitive RT-PCR is shown in Fig. 2. Here, a fixed amount of target RNA is reverse-transcribed and amplified together with increasing amounts of an internal RNA standard of known amount using the same primer set in the same reaction. The quantity of target RNA is determined by observing the relative amount of target and standard products resulting from RT-PCR with the initial target concentration calculated as the value of the standard which gives the same value after RT-PCR is completed (i.e., when $\log _{10}$ (target $\cdot$ stan$\left.\operatorname{dard}^{-1}\right)=0$ or target $\cdot$ standard $^{-1}=1$ ). Standards were constructed using the procedure described earlier as was the RT-PCR reaction (Han and Semrau, 2004). Briefly, the RT-PCR reaction was carried out in 50-mL samples consisting of $5 \mathrm{~mL}$ of standard RNA, $5 \mu \mathrm{L}$ total RNA, $10 \mu \mathrm{L} 5 \times \mathrm{RT}$-PCR buffer, $10 \mu \mathrm{L} 5 \times \mathrm{Q}$ solution, 400 $\mu \mathrm{M}$ of each dNTP, $0.6 \mu \mathrm{M}$ of each primer, and $2 \mu \mathrm{L}$ of Qiagen OneStep RT-PCR enzyme. The sequences of primers to reverse transcribe and amplify both targets and standards have been reported earlier (Han and Semrau,

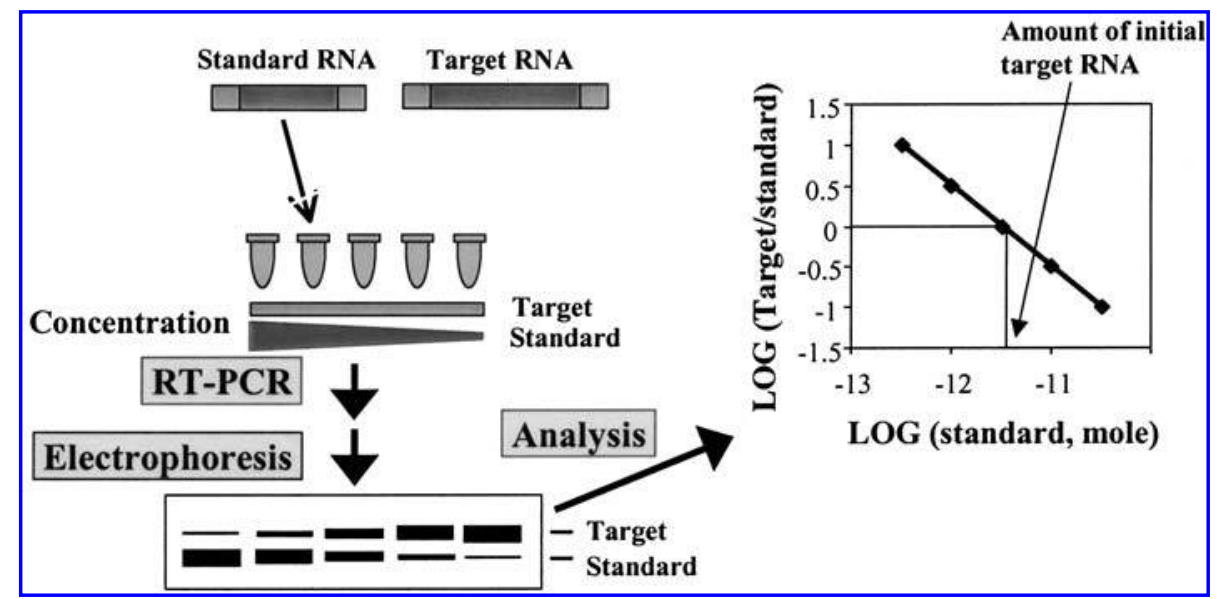

Figure 2. Multistep procedure for competitive reverse transcription-polymerase chain reaction for quantification of gene expression. 
Table 1. Primer sequences used for RT-PCR of $p m o A$ and $m m o X$ transcripts.

\begin{tabular}{lll}
\hline Primer & \multicolumn{1}{c}{ Sequence $\left(5^{\prime} \rightarrow 3^{\prime}\right)^{\mathrm{a}}$} & Reference \\
\hline pmoA & & Cheng et al. (1999) \\
Forward & GGGGGAACTTCTGGGGITGGAC & Cheng et al. (1999) \\
Reverse & GGGGGRCAACGTCYTTACCGAA & McDonald et al. (1995) \\
Forward & & McDonald et al. (1995) \\
Reverse & GGCTCCAAGTTCAAGGTCGAGC & TGGCACTCGTAGCGCTCCGGCTCG \\
\hline
\end{tabular}

${ }^{\mathrm{a}} \mathrm{R}=\mathrm{A}$ or $\mathrm{G} ; \mathrm{Y}=\mathrm{C}$ or $\mathrm{T} ; \mathrm{I}=$ deoxyinosine.

2004) and are shown in Table 1. Following an RT incubation at $50^{\circ} \mathrm{C}$ for $30 \mathrm{~min}$ and heating to $95^{\circ} \mathrm{C}$ for 15 min, 40 PCR cycles with the following amplification profile were conducted: $94^{\circ} \mathrm{C}$ for $1 \mathrm{~min} ; 55^{\circ} \mathrm{C}$ for $1 \mathrm{~min}$; and $72^{\circ} \mathrm{C}$ for $1 \mathrm{~min}$. Finally, all samples were extended at $72^{\circ} \mathrm{C}$ for $10 \mathrm{~min}$. RT-PCR products were analyzed by electrophoresis in $2.5 \%$ agarose gels. After scanning to digitize the photographs of the gels, the images were analyzed on NIH image (http://rsb.info.nih.gov/nih-image) to generate a value proportional to the intensity of the ethidium bromide-stained band.

\section{Naphthalene assay for whole-cell sMMO activity}

As an independent verification if sMMO was being expressed, the specific naphthalene assay (Brusseau et al., 1990) was used for all samples.

\section{RESULTS AND DISCUSSION}

\section{Methane oxidation}

The rate of methane oxidation by methanotrophs was assumed to follow Michaelis-Menten kinetics, since it has been shown that methane oxidation by pure methanotroph cultures is well described by this rate law (Hanson and Hanson, 1996). Kinetic parameters for the Schoolcraft mixed methanotroph consortia are reported in Table 2. A comparison of the apparent first-order rate constant $V_{\max } / K_{s}$ for methane consumption for the Schoolcraft mixed culture with published values for pure methanotroph cultures is also presented in Table 2.

The apparent maximal degradation rate measured for the Schoolcraft methanotroph consortia falls within the range of $V_{\max }$ values previously reported by Hanson and Hanson (1996) for pure methanotroph cultures, 80 to 260 $\mathrm{nmol} \cdot \min ^{-1} \cdot(\mathrm{mg} \text { protein })^{-1}$. The apparent affinity $K_{s}$ for the Schoolcraft mixed culture slightly exceeds the reported range of 0.8 to $9.3 \mu \mathrm{M}$ for pure methanotroph cultures. Overall, however, the methane oxidation kinetics of the Schoolcraft methanotroph population is comparable to that of pure methanotroph cultures, as indicated by Table 2.

\section{Chloroethylene cometabolism}

Since the objective of the Schoolcraft Plume G bioremediation effort is to remove chlorinated solvents from

Table 2. Michaelis-Menten rate law parameters for methane and chloroethylene oxidation by Schoolcraft methanotroph consortia at $30^{\circ} \mathrm{C}$; and comparison of apparent first-order rate constants for Plume $\mathrm{G}$ mixed methanotrophs with pure methanotroph cultures.

\begin{tabular}{|c|c|c|c|c|c|c|c|}
\hline & \multirow{3}{*}{$\begin{array}{c}\mathrm{V}_{\max } \\
(\text { nmol/min } \\
\text { mg protein) }\end{array}$} & \multirow{3}{*}{$\begin{array}{c}\mathrm{K}_{s} \\
(\mu M)\end{array}$} & \multirow{3}{*}{$\begin{array}{c}\text { Range } \\
(\mu M)\end{array}$} & \multicolumn{4}{|c|}{$\mathrm{V}_{\max } / \mathrm{K}_{\mathrm{s}}(\mathrm{ml}$ min $/ m g$ protein $)$} \\
\hline & & & & \multirow{2}{*}{$\begin{array}{c}\begin{array}{c}\text { Schoolcraft } \\
\text { methanotrophs }\end{array} \\
\text { pMMO }\end{array}$} & \multicolumn{2}{|c|}{$\begin{array}{c}\text { M. trichosporium } \\
\text { OB3b } \\
\text { (van Hylckama Vlieg, } \\
\text { et al. 1996) }\end{array}$} & \multirow{2}{*}{$\begin{array}{c}\text { M. album } \\
B G 8 \\
\text { (Han et al. } \\
1999) \\
p M M O\end{array}$} \\
\hline & & & & & $p M M O$ & $s M M O$ & \\
\hline Methane & $178 \pm 9$ & $12.2 \pm 1.0$ & $5-83$ & $14.6 \pm 1.9$ & $4.9^{\mathrm{a}}$ & $4.9^{\mathrm{a}}$ & 25 \\
\hline $\mathrm{VC}$ & $9.9 \pm 0.8$ & $47 \pm 10$ & $10-100$ & $0.21 \pm 0.06$ & 3.8 & 15.2 & 0.23 \\
\hline$c$-DCE & $0.52 \pm 0.10$ & $3.1 \pm 0.7$ & $0.5-8$ & $0.17 \pm 0.07$ & 0.12 & 9.8 & 0.15 \\
\hline TCE & $1.3 \pm 0.2$ & $44 \pm 4$ & $2.5-60$ & $0.030 \pm 0.007$ & $<0.06$ & 6.2 & 0.072 \\
\hline
\end{tabular}

aReference: Lontoh and Semrau, 1998. 
the groundwater, the $\mathrm{VC}, c$-DCE and TCE degradation kinetics of the indigenous Schoolcraft methanotrophs were measured. Methanotrophs are ubiquitous in the environment (Hanson and Hanson, 1996), and have been shown to degrade chloroethylene compounds cometabolically (Ensley, 1991). As such, the use of methanotrophs in sequential anaerobic/aerobic treatment schemes is of interest for remediation of the Schoolcraft plume. Michaelis-Menten rate law parameters for chloroethylene degradation in the absence of methane but in the presence of $20 \mathrm{mM}$ formate as sodium formate are reported in Table 2. The studies reported here, as well as the data from other researchers in Table 2, were performed in the absence of methane and in the presence of formate to ensure that neither substrate inhibition nor limiting reducing equivalents affected the measured kinetic parameters. It should be noted that the concentration range sampled for $c$-DCE cometabolism was smaller than the ranges sampled for the other two chloroethylene compounds. This was done to insure that the $c$-DCE concentration did not fall into the range of toxicity for pMMOexpressing methanotrophs (Ensley, 1991). The source of $c$-DCE has trace amounts of chloroform of $\sim 0.4 \%$ $\mathrm{mol} / \mathrm{mol}$ (Maymó-Gatell et al., 2001). Chloroform at a concentration of $100 \mu \mathrm{M}$ has been shown to affect methanotrophic activity when expressing pMMO (Han et al., 1999). It is possible that the presence of chloroform may have affected methanotrophic activity in these experiments, but the predicted concentration of chloroform using the findings of Maymo-Gatell et al. (2001) is less than $40 \mathrm{nM}$, suggesting that $c$-DCE itself is toxic to these cells.

Predictably, the cometabolism rates for the chloroethylenes are much slower than the rate at which the methanotrophs consume methane. It is additionally observed in Table 2 that the apparent first order rate constants VC and $c$-DCE are approximately of equal magnitude, whereas cometabolism of TCE by the Schoolcraft mixed methanotroph consortia is much slower than for $\mathrm{VC}$ or $c$-DCE.
These observed trends are consistent with published kinetic data for pure cultures of pMMO-expressing M. album BG8 (Han et al., 1999) and for pMMOand sMMO-expressing $M$. trichosporium OB3b (van Hylckama Vlieg et al., 1996). From a comparison of the apparent first-order chloroethylene degradation rate constants of these methanotrophs with the kinetic results obtained for the indigenous Schoolcraft methanotrophs, it is evident that the Schoolcraft consortium is primarily composed of pMMO-expressing methanotrophs. The similarity between the VC, $c$-DCE, and TCE degradation rate constants for the native Schoolcraft mixed methanotrophs and the pMMO-expressing M. album BG8 pure culture is particularly noteworthy.

The use of formate to act as source of exogenous reducing equivalents has been commonly used in laboratory studies of pollutant degradation by methanotrophs (Alvarez-Cohen and McCarty, 1991; Henry and GrbícGalic, 1991; van Hylckama Vlieg et al., 1996; Lontoh and Semrau, 1998; Han et al., 1999). It may be advantageous to add formate as part of in situ remediation strategies emphasizing methanotrophic activity, as there have been no reported aerobic methylotrophic bacteria that can utilize formate as the sole carbon and energy source (Lidstrom, 2001). As such, competition between methanotrophs and other in situ community members for formate may be small, allowing methanotrophs to be the predominant cells oxidizing formate and thus generating reducing equivalents necessary for extended pollutant degradation.

\section{Molecular analysis}

To characterize the Schoolcraft methanotrophic population that was stimulated and responsible for pollutant degradation, total RNA and DNA were isolated from Schoolcraft groundwater amended with $0.1 \times$ NMS and from a slurry of Schoolcraft soil in NMS medium, as described in the Materials and Methods section. From both
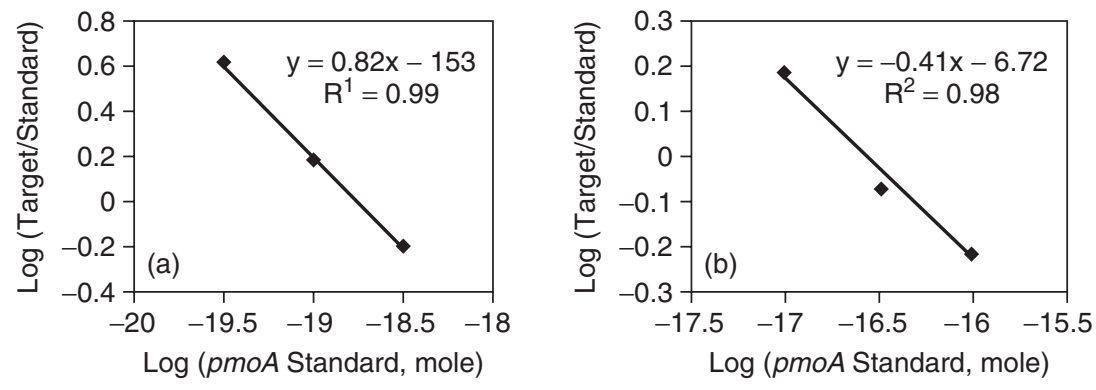

Figure 3. RT-PCR of $p m o A$ mRNA from (a) soil slurries and (b) amended groundwater, respectively. 
total RNA samples, only pmoA mRNA was found using competitive RT-PCR. This result is consistent with the copper concentration in the groundwater, $2.5 \mu \mathrm{M}$, at which sMMO expression is known to be repressed. Negative response of the naphthalene assay, which is used to selectively measure sMMO activity, confirmed this finding (data not shown). To our knowledge, this is the first time the naphthalene assay has been used to monitor sMMO expression in methanotrophic enrichments.

The level of pmoA mRNA transcripts were quantified from both samples using competitive RT-PCR. The total RNA of groundwater was found to contain (2.65 \pm $0.43) \times 10^{-16}$ mole $p m o A \mathrm{mRNA} / \mu \mathrm{L}$ while in soil slurries $(1.57 \pm 0.10) \times 10^{-17}$ mole $p m o A$ mRNA/g wet soil was measured as indicated in Fig. 3. The amount of $p m o A$ expression is comparable to that found earlier using a model system of M. trichosporium OB3b both in the presence and absence of a sandy aquifer soil from Wagner, MI, similar to that found at the Schoolcraft site (Han and Semrau, 2004). The amplified 330-bp pmoA was also sequenced and compared with the GenBank nucleotide databases using BLAST to determine how similar it was to known $p m o A$ genes. pmoA genes from genus Methylocystis showed the highest identity (98\%). This genus is representative of Type II methanotrophs, cells that utilize the serine pathway for carbon assimilation. Type II methanotrophs have been observed to express sMMO, but it should be noted that at least one Methylocystis strain, Methylocystis parvus OBBP does not express sMMO (Tsien and Hanson, 1992), and so more information must be collected to determine if any members of the enriched methanotrophic community from the Schoolcraft site can express sMMO.

\section{SUMMARY}

Native mixed methanotrophs at the Schoolcraft Plume $\mathrm{G}$ bioremediation site were found to be capable of cometabolizing TCE, $c$-DCE, and $\mathrm{VC}$ at rates comparable to those of pure methanotroph cultures expressing pMMO. Molecular analysis of total RNA and RT-PCR assays found no sMMO-expression by these cells, nor was any naphthalene oxidation observed within the Schoolcraft methanotroph consortium. Although as shown in Table 2, cells expressing sMMO have higher pseudo-firstorder rate constants for chlorinated ethane oxidation, attempts to stimulate in situ methanotrophic communities can enhance pMMO expression. As such, these findings suggest that laboratory studies using single methanotroph cultures expressing pMMO may serve as appropriate surrogates for the measurement of Michaelis-Menten kinetic parameters for design and performance modeling of aer- obic in situ bioremediation systems utilizing oxygen delivery to stimulate methanotrophic cometabolism of chlorinated solvents.

\section{ACKNOWLEDGMENTS}

Research support from the State of Michigan Department of Environmental Quality contract Y40386 (to C.M.L.) and the National Science Foundation grant MCB-9708557 (to J.D.S.) is gratefully acknowledged.

\section{REFERENCES}

ALVAREZ-COHEN, L., and MCCARTY, P.L. (1991). Effects of toxicity, aeration, and reductant supply on trichloroethylene transformation by a mixed methanotrophic culture. Appl. Environ. Microbiol. 57, 228-235.

ARNOLD, W.A., and ROBERTS, A.L. (2000). Inter- and intraspecies competitive effects in reactions of chlorinated ethylenes with zero-valent iron in column reactors. Environ. Eng. Sci. 17, 291-302.

ARP, D.J. (1995). Understanding the diversity of trichloroethylene co-oxidations. Curr. Opin. Biotechnol. 6, 352-358.

BOUWER, E.J., and MCCARTY, P.L. (1983). Transformation of 1- and 2-carbon halogenated aliphatic compounds under methanogenic conditions. Appl. Environ. Microbiol. 45, 1286-1294.

BRADLEY, P.M., and F.H. CHAPELLE. (2000). Aerobic microbial mineralization of dichloroethene as sole carbon substrate. Environ. Sci. Technol. 34, 221-223.

BRUSSEAU, G.A., TSIEN, H.-C., HANSON, R.S., and WACKETT, L.P. (1990). Optimization of trichloroethylene oxidation by methanotrophs and the use of a colorimetric assay to detect soluble methane monooxygenase activity. Biodegradation 1, 19-29.

CHANG, H.L., and ALVAREZ-COHEN, L. (1996). Biodegradation of individual and multiple chlorinated aliphatic hydrocarbons by methane-oxidizing cultures. Appl. Environ. Microbiol. 62, 3371-3377.

CHENG, Y.S., HALSEY, J.L., FODE, K.A., REMSEN, C.C., and COLLINS, M.L.P. (1999). Detection of methanotrophs in groundwater by PCR. Appl. Environ. Microbiol. 65, 648-651.

COLEMAN, N.V., T.E. MATTES, J.M. GOSSETT, and SPAIN, J.C. (2002). Phylogenetic and kinetic diversity of aerobic vinyl chloride-assimilating bacteria from contaminated sites. Appl. Env. Microbiol. 68, 6162-6171.

DEDYSH, S.N., LIESACK, W., KHMELENINA, V.N., SUZINA, N.E., TROTSENKO, Y.A., SEMRAU, J.D., BARES, A.M., PANIKOV, N.S., and TIEDJE, J.M. (2000). Methylocella palustris gen. nov., sp. nov., a new methane-oxidizing acidophilic bacterium from peat bogs, representing a novel subtype of serine-pathway methanotrophs. Int. J. Syst. Evol. Microbiol. 50, 955-969. 
DISTEFANO, T.D., GOSSETT, J.M., AND ZINDER, S.H. (1991). Reductive dechlorination of high concentrations of tetrachloroethene to ethane by an anaerobic enrichment culture in the absence of methanogenesis. Appl. Environ. Microbiol. 57, 2287-2292.

ENSLEY, B.D. (1991). Biochemical diversity of trichloroethylene metabolism. Ann. Rev. Microbiol. 45, 283-299.

FREEDMAN, D.L., and GOSSETT, J.M. (1989). Biological reductive dechlorination of tetrachloroethylene and trichloroethylene to ethylene under methanogenic conditions. Appl. Environ. Microbiol. 55, 2144-2151.

GOSSET, J.M. (1987). Measurement of Henry's Law constants for $\mathrm{C}_{1}$ and $\mathrm{C}_{2}$ chlorinated hydrocarbon. Environ. Sci. Technol. 21, 202-208.

HAN, J-I., LONTOH, S., and SEMRAU, J.D. (1999). Degradation of chlorinated and brominated hydrocarbons by Methylomicrobium album BG8. Arch. Microbiol. 172, 393-400.

HAN, J-I., and SEMRAU, J.D. (2004). Quantification of gene expression in methanotrophs by competitive reverse transcription polymerase chain reaction. Environ. Microbiol. 6, 388-399.

HANSON, R.S., and HANSON, T.E. (1996). Methanotrophic bacteria. Microbiol. Rev. 60, 439-471.

HARTMANS, S., and DE BONT, J.A.M. (1992). Aerobic vinyl chloride metabolism in Mycobacterium aurum L1. Appl. Env. Microbiol. 58, 1220-1226.

HE, J.Z., SUNG, Y., DOLLHOPF, M.E., FATHEPURE, B.Z., TIEDJE, J.M., and LOFFLER, F.E. (2002). Acetate versus hydrogen as direct electron donors to stimulate the microbial reductive dechlorination process at chloroethene-contaminated sites. Environ. Sci. Technol. 36, 3945-3952 [Erratum: He, J.Z. et al. (2003). Environ. Sci. Technol. 37, 816].

HENRY, S.M., and GRBÍC-GALÍC, D. (1991). Influence of endogenous and exogenous electron donors and trichloroethylene oxidation toxicity on trichloroethylene oxidation by methanotrophic cultures from a groundwater aquifer. Appl. Environ. Microbiol. 57, 236-244.

HERON, G., GIERKE, J.S., FAULKNER, B., MRAVIK, S., WOOD, L., and ENFIELD, C.G. (2002). Pulsed air sparging in aquifers contaminated with dense nonaqueous phase liquids. Ground Water Monit. Remediat. 22, 73-82.

HEYWOOD, D. (1993). Michigan Department of Environmental Quality groundwater monitoring data for MDEQ site \# 390052. Groundwater sampling conducted by Brown and Root Environmental. Data obtained by personal communication.

HOLLIGER, C., HAHN, D., HARMSEN, H., LUDWIG, W., SHUMACHER, W., TINDALL, B., VAZQUEZ, F., WEISS, N., and ZEHNDER, A.J.B. (1998). Dehalobacter restrictus gen. nov. and sp. nov., a strictly anaerobic bacterium that reductively dechlorinates tetra- and trichloroethene in an anaerobic respiration. Arch. Microbiol. 169, 313-321.

KIM, H.K., DYBAS, L., MAYOTTE, T., HASHSHAM, S., and DYBAS, M.J. (2001). Anaerobic dechlorination of chlorinated solvents: Effects of several electron donors on dehalogenation in anaerobic soil microcosms. Battelle Bioremediation Symposium, San Diego, CA, Abstract C1:53.
LIDSTROM, M.E. (2001). Aerobic Methylotrophic Prokaryotes. In M. Dworkin et al., Eds., The Prokaryotes: An Evolving Electronic Resource for the Microbiological Community, 3rd ed., release 3.7, November 2, 2001. New York: Springer-Verlag. (http://link.springer-ny.com/link/service/ books/10125/).

LONTOH, S., and SEMRAU, J.D. (1998). Methane and trichloroethylene degradation by Methylosinus trichosporium OB3b expressing particulate methane monooxygenase. Appl. Environ. Microbiol. 64, 1106-1114.

MAYMÓ-GATELL, X., CHIEN, Y., GOSSETT, J.M., and ZINDER, S.H. (1997). Isolation of a bacterium that reductively dechlorinates tetrachloroethene to ethene. Science $\mathbf{2 7 6}$, 1568-1571.

MAYMÓ-GATELL, X., NIJENHUIS, I., and ZINDER, S.H. (2001). Reductive dechlorination of cis-1,2-dichloroethene and vinyl chloride by Dehalococcodies ethenogenes. Environ. Sci. Technol. 35, 516-521.

MCDONALD, I.R., KENNA, E.M., and MURRELL, J.C. (1995). Detection of methanotrophic bacteria in environmental samples with the PCR. Appl. Environ. Microbiol. 61, $116-121$.

MIDDELDORP, P.J.M., VAN AALST, M.A., RIJNAARTS, H.H.M., STAMS, F.J.M., and DE KREUK, H.F. (1998). Stimulation of reductive dechlorination for in situ bioremediation of a soil contaminated with chlorinated ethenes. Water Sci. Technol. 37, 105-110.

MILLER, E. WOHLFARTH, G., and DIEKERT, G. (1997). Studies on tetrachloroethene respiration in Dehalospirillum multivorans. Arch. Microbiol. 166, 379-387.

MOREL, F.M.M., and HERING, J.G. (1991). Principles and Applications of Aquatic Chemistry. New York: John Wiley \& Sons, pp. 181-193.

MORKIN, M., DEVLIN, J.F., BARKER, J.F., and BUTLER, B.J. (2000). In situ sequential treatment of a mixed contaminant plume. J. Contam. Hydrol. 45, 283-302.

STEFFAN, R.J., SPERRY, K.L., WALSH, M.T., VAINBERG, S., and CONDEE, C.W. (1999). Field-scale evaluation of in situ bioaugmentation for remediation of chlorinated solvents in groundwater. Environ. Sci. Technol. 33, 2771-2781.

TSE, G., ORBEY, H., and SANDLER, S.I. (1992). Infinite dilution activity coefficients and Henry's Law coefficients of some priority water pollutants determined by a relative gas-chromatographic method. Environ. Sci. Technol. 26, 2017-2022.

TSIEN, H-C., and HANSON, R.S. (1992). Soluble methane monooxygenase component $\mathrm{B}$ gene probe for identification of methanotrophs that rapidly degrade trichloroethylene. Appl. Environ. Microbiol. 58, 953-960.

van HYLCKAMA VLIEG, J.E.T., DE KONING, W., and JANSSEN, D.B. (1996). Transformation kinetics of chlorinated ethenes by Methylosinus trichosporium OB3b and detection of unstable epoxides by on-line gas chromatography. Appl. Environ. Microbiol. 62, 3304-3312.

VERCE, M.F., GUNSCH, C.G., DANKO, A.S., and FREEDMAN, D.L. (2002). Cometabolism of cis-1,2-dichloroethene by aerobic cultures grown on vinyl chloride as the primary substrace. Environ. Sci. Technol. 36, 2171-2177. 
VOGEL, T.M., and MCCARTY, P.L. (1985). Biotransformation of tetrachloroethylene, dichloroethylene, vinyl chloride, and carbon dioxide under methanogenic conditions. Appl. Environ. Microbiol. 49, 1080-1083.

WACKETT, L.P. (1995). Bacterial co-metabolism of halogenated organic compounds. In Microbial Transformation and Degradation of Toxic Organic Chemicals. New York: Wiley-Liss, Inc., pp. 217-241.
WHITTENBURY, R.K., PHILLIPS, K.D., and WILKENSON, J.F. (1970). Enrichment, isolation and some properties of methane-utilizing bacteria. J.Gen. Microbiol. 61, 205-218.

WIEDEMEIER, T.H., RIFAI, H.S., NEWELL, C.J., and WILSON, J.T. (1999). Natural Attenuation of Fuels and Chlorinated Solvents in the Subsurface. New York: John Wiley \& Sons, pp. 241-297. 